\title{
A Review of Optimization Researches in the Field of Agricultural Supply Chain
}

ISSN: 2637-7659

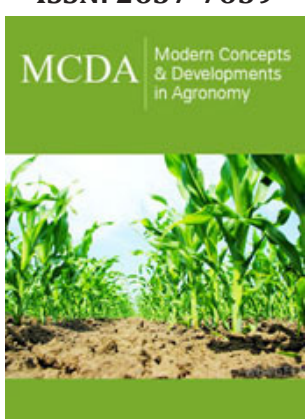

*Corresponding author: Armin Cheraghalipour, Department of Industrial Engineering, KN Toosi University of Technology, Tehran, Iran

Submission: 畘 January 07, 2020

Published: 笽January 22, 2020

Volume 5 - Issue 4

How to cite this article: Armin C, Emad Roghanian. A Review of Optimization Researches in the Field of Agricultural Supply Chain. Mod Concep Dev Agrono.5(4). MCDA.000619.2020. DOI: 10.31031/MCDA.2020.05.000619

Copyright@ Armin Cheraghalipour, This article is distributed under the terms of the Creative Commons Attribution 4.0 International License, which permits unrestricted use and redistribution provided that the original author and source are credited.

\author{
Armin Cheraghalipour* and Emad Roghanian
}

Department of industrial engineering, KN Toosi University of Technology, Iran

\begin{abstract}
The position of the agricultural sector as a driving force for economic growth and development in the urban and rural structure is one of the issues that has always been the subject of expert opinion. A considerable amount of perishable products especially in the food and agriculture is corrupted annually due to the lack of an effective mechanism in the supply chain. This forces researchers to plan and design mathematical models to improve this situation. One of the most important tools in this field is supply chain network design, which the researchers are trying to improve in the current human society by extending this tool for the agriculture sector. For this purpose, in this research, we will briefly review some of the work done. Finally, research gaps are provided for future research.
\end{abstract}

\section{Introduction}

In today's world, one of the basic problems of mankind is supplying food needs, so that food security and quality assurance have become important goals of governments. In particular, agricultural production has received special attention in developing countries [1]. Crops are those agricultural products that have less than one year of planting and flowering (end of life). In fact, their lifecycle lasts less than a year; most crops are stored for several months and only a part of the crop is directly consumed after harvest; Therefore, most small and large producers prefer to stock these relatively sensitive crops for several months to provide fruit in early spring, as well as reasonable prices due to market demand; Therefore, it is necessary to have suitable places for storing high volume of manufactured products and having a schedule. Also, because most warehouses are traditional, so every year a large volume of products made with great effort and expense, these warehouses suffer a severe loss of quality [2]. The agricultural supply chain today has played an important role in supply chain issues because of its unique characteristics such as the importance of food quality, supply, climate change and price changes [3]. These products are categorized in terms of shelf life into perishable and non-perishable (such as grain and nuts) and in terms of life cycle into agricultural and horticultural products [4]. In recent years, the importance of fresh fruit has grown substantially with increasing demand from concerned consumers for a healthy diet. This has made the quality and availability of fruit throughout the year a significant issue [5]. Only in the past ten years has the agri-food industry in general and the fresh fruit sector been specifically recognized and discussed in the supply chain as a key concept for competitiveness [6,7]. For the first time, Ahumada and Villalobos conducted a study of model planning in the agricultural supply chain. They have presented their research overview of articles available since 1985 focusing on various crops including perishable, non-perishable, and most vegetables [8]. Audsley [9] also did research with an operation research model in the agricultural sector but limited to examining developments in the United Kingdom [9]. Furthermore, Zhang [10] presented an interesting version of mathematical models for the crop industry including fruits, vegetables, grapes, ornamental plants, tree nuts, berries and dried fruits [10]. On the other hand, Shukla and Jharkharia provided a summary of the existing literature from 1991 to 2011 on the production of fresh produce such as fruits, flowers and vegetables [11].

The main feature of their paper is to focus on the articles studied in the field of perishable, non-perishable and fresh produce. They also categorized the literature studied 
by geographical area and journal. To focus more on supply chain features, Farahani et al. [12] provided examples of decisions made in generic supply chains, while Tsolakis et al. [13] presented the type of decision making in agricultural supply chains. The process of this investigation continues, and more attention is being paid to this issue by 2019. For example, over the past two years, Cheraghalipour et al. [2] have done several important researches in the field of citrus $[3,14,15]$ and rice [7] supply chains, which considering the high assumptions have led to the complexity of their model and proximity to the real world. In their recently published work [15], they attempt to optimize total costs of the chain, demand responsiveness, and $\mathrm{CO} 2$ emissions reduction. They used a novel multi-objective metaheuristic called tree growth algorithm $[16,17]$ to solve their model (Figure 1). Due to the large number of articles in this field, some of the other articles are reported in Tables 1 \& 2 [18-24]. On the other hands, Figure 2 is illustrated to realize the research labelled in Table 2 [25-35].
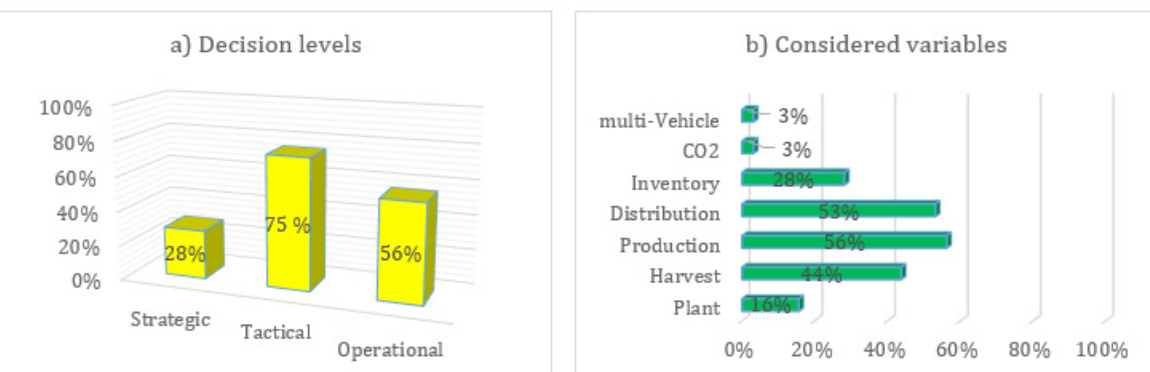

Figure 1: Percentage of research in Table 1 that considers its assumptions.
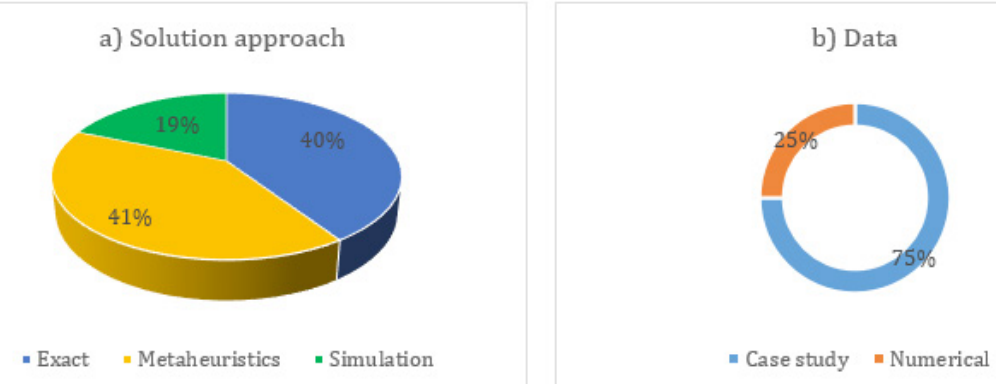

Figure 2: Percentage of research in Table 2 that considers its assumptions.

Table 1: Classifying related work on agricultural supply chain in terms of decision levels and variables.

\begin{tabular}{|c|c|c|c|c|c|c|c|c|c|c|}
\hline \multirow{2}{*}{ Reference } & \multicolumn{3}{|c|}{ Decision Levels } & \multicolumn{7}{|c|}{ Considered Variables } \\
\hline & Strategic & Tactical & Operational & Plant & Harvest & Production & Distribution & Inventory & $\mathrm{CO}_{2}$ & Vehicle \\
\hline [18] & & $*$ & $*$ & $*$ & $*$ & & & & & Single \\
\hline [19] & & $*$ & & & $*$ & & & & & Single \\
\hline$[20]$ & & $*$ & & & & & * & $*$ & & Single \\
\hline [21] & & * & & & & & $*$ & & & Single \\
\hline [22] & & * & & & & & $*$ & & & Single \\
\hline [23] & $*$ & & & $*$ & $*$ & $*$ & & & & Single \\
\hline [24] & & & $*$ & & $*$ & $*$ & & & & Single \\
\hline [25] & $*$ & $*$ & & & & $*$ & & & & Single \\
\hline [26] & & * & $*$ & & $*$ & $*$ & & & & Single \\
\hline [27] & $*$ & * & & & & $*$ & $*$ & & & Single \\
\hline [28] & & * & $*$ & & & * & * & $*$ & & Single \\
\hline [29] & & $*$ & $*$ & & & & & & & Single \\
\hline [30] & $*$ & $*$ & & $*$ & $*$ & $*$ & & & & Single \\
\hline [31] & & & $*$ & & & & $*$ & $*$ & & Single \\
\hline
\end{tabular}




\begin{tabular}{|c|c|c|c|c|c|c|c|c|c|c|}
\hline [32] & $*$ & $*$ & & & & & $*$ & $*$ & & Single \\
\hline [33] & & $*$ & & & & $*$ & $*$ & & & Single \\
\hline [34] & & $*$ & $*$ & & $*$ & & $*$ & & & Single \\
\hline [35] & & $*$ & $*$ & & $*$ & & & & & Single \\
\hline [36] & & $*$ & * & & & $*$ & $*$ & & & Single \\
\hline [37] & & & $*$ & & & & & $*$ & & Single \\
\hline [38] & & $*$ & & & & $*$ & & & & Single \\
\hline [39] & & & * & & $*$ & & & & & Single \\
\hline [40] & $*$ & & & $*$ & & $*$ & & & & Single \\
\hline [41] & & $*$ & & & & $*$ & $*$ & & & Single \\
\hline [42] & & * & & & & $*$ & & & & Single \\
\hline [43] & & $*$ & $*$ & & $*$ & & & & & Single \\
\hline [44] & & & $*$ & & & & $*$ & $*$ & & Single \\
\hline [3] & $*$ & $*$ & $*$ & & $*$ & $*$ & $*$ & $*$ & & Single \\
\hline [45] & & $*$ & $*$ & & & $*$ & $*$ & & & Single \\
\hline [46] & & $*$ & $*$ & & * & * & $*$ & & & Single \\
\hline [7] & $*$ & & * & * & $*$ & $*$ & $*$ & $*$ & & Single \\
\hline [15] & $*$ & $*$ & $*$ & & $*$ & $*$ & $*$ & $*$ & $*$ & Multiple \\
\hline
\end{tabular}

Table 2: Classifying related work on agricultural supply chain in terms of solution approach, network flow and data.

\begin{tabular}{|c|c|c|c|c|c|c|c|c|}
\hline \multirow{2}{*}{ Reference } & \multicolumn{3}{|c|}{ Solution Approach } & \multicolumn{3}{|c|}{ Network Flow } & \multicolumn{2}{|c|}{ Data } \\
\hline & Exact & Metaheuristics & Simulation & Forward & Reverse & Closed loop & Case study & Numerical \\
\hline [18] & $*$ & & & $*$ & & & $*$ & \\
\hline [19] & & $*$ & & $*$ & & & $*$ & \\
\hline [20] & * & & & * & & & * & \\
\hline [21] & & & * & * & & & & $*$ \\
\hline [22] & & $*$ & & * & & & & * \\
\hline [23] & & $*$ & & * & & & * & \\
\hline [24] & $*$ & & & * & & & * & \\
\hline [25] & $*$ & & & * & & & * & \\
\hline [26] & * & 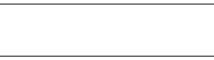 & & * & & & * & \\
\hline [27] & * & & & * & & & * & \\
\hline$[28]$ & $*$ & 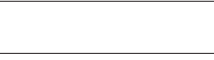 & & * & & & * & \\
\hline [29] & & * & & * & & & $*$ & \\
\hline [30] & & $*$ & & $*$ & & & * & \\
\hline [31] & & $*$ & & $*$ & & & & * \\
\hline [32] & & & $*$ & $*$ & & & & $*$ \\
\hline [33] & & * & & * & & & * & \\
\hline [34] & & * & & * & & & * & \\
\hline [35] & $*$ & & & $*$ & & & $*$ & \\
\hline [36] & & * & & $*$ & & & & * \\
\hline [37] & & $*$ & & $*$ & & & & $*$ \\
\hline [38] & $*$ & & & $*$ & & & * & \\
\hline [39] & & & * & $*$ & & & $*$ & \\
\hline
\end{tabular}




\begin{tabular}{|c|c|c|c|c|c|c|c|c|}
\hline [40] & $*$ & & & $*$ & & & $*$ & \\
\hline [41] & $*$ & & & $*$ & & & & $*$ \\
\hline [42] & & & $*$ & $*$ & & & & * \\
\hline [43] & $*$ & & & $*$ & & & $*$ & \\
\hline [44] & $*$ & & & $*$ & & & $*$ & \\
\hline [3] & & $*$ & & $*$ & $*$ & $*$ & $*$ & \\
\hline [45] & & & $*$ & $*$ & & & $*$ & \\
\hline [46] & & & $*$ & $*$ & & & $*$ & \\
\hline [7] & & $*$ & & $*$ & & & $*$ & \\
\hline [15] & * & $*$ & & $*$ & $*$ & * & $*$ & \\
\hline
\end{tabular}

As is displayed in this Figure 2, metaheuristics approach covers $41 \%$, exact method covers about $40 \%$, and simulation aid about $19 \%$ of these researches [36-42]. Also, most of these research $(75 \%)$ consider case study to accumulate data for their model parameters [43-46]. Besides, Table 2 shows that all of these researches considered forward flows, while only two researches considered reverse flows or closed-loop network. To summarize, it can be mentioned that we have briefly reviewed the research until 2019 in the field of agricultural supply chains. After descripting the main subject, we attempt to find the behavior of 32 researches in terms of various assumptions such as decision levels, considered variables, solution approach, network flows, and type of data. After reviewing and summarizing, the following gaps were identified for future research.

A. Due to the above-mentioned gaps, the future works can cover strategic level in their research formulation.

B. The future works can more emphasis to some variables such as multi-vehicle, $\mathrm{CO} 2$ emission, and planting crops.

C. They can consider reverse flows and closed-loop structure in their network design.

D. Based on the reported results, they can use metaheuristic algorithms for large size problems.

\section{References}

1. Ahumada O, Villalobos JR, Mason AN (2012) Tactical planning of the production and distribution of fresh agricultural products under uncertainty. Agric Syst 112: 17-26.

2. Cheraghalipour A, Paydar MM, Keshteli MH (2017) A multi-period and three-echelon supply chain network design for perishable agricultural products using meta-heuristic algorithms. J Oper Res Its Appl 14(3): 1524.

3. Cheraghalipour A, Paydar MM, Keshteli MH (2018) A Bi-objective optimization for citrus closed-loop supply chain using pareto-based algorithms. Appl Soft Comput 69: 33-59.

4. O Ahumada, JR Villalobos (2011) A tactical model for planning the production and distribution of fresh produce. Ann Oper Res 190: 339358.

5. O Ahumada, JR Villalobos (2011) Operational model for planning the harvest and distribution of perishable agricultural products. Int J Prod Econ 133(2): 677-687.

6. Cheraghalipour A, Paydar MM, Keshteli MH (2018) Applying a hybrid BWM-VIKOR approach to supplier selection: a case study in the Iranian agricultural implements industry. Int J Appl Decis Sci 11(3): 274-301.

7. Cheraghalipour A, Paydar MM, Keshteli MH (2019) Designing and solving a bi-level model for rice supply chain using the evolutionary algorithms. Comput Electron Agric 162: 651-668.

8. O Ahumada, JR Villalobos (2009) Application of planning models in the agri-food supply chain: A review. Eur J Oper Res 196(1): 1-20.

9. Audsley E, Sandars DL (2009) A review of the practice and achievements from 50 years of applying OR to agricultural systems in Britain. OR Insight 22(1): 2-18.

10. Zhang W, Wilhelm WE (2011) OR/MS decision support models for the specialty crops industry: a literature review. Ann Oper Res 190: 131148.

11. Shukla M, Jharkharia S (2013) Agri-fresh produce supply chain management: a state-of-the-art literature review. Int J Oper Prod Manag 33(2): 114-158.

12. Farahani RZ, Rezapour S, Drezner T, Fallah S (2014) Competitive supply chain network design: An overview of classifications, models, solution techniques and applications. Omega 45: 92-118.

13. Tsolakis NK, Keramydas CA, Toka AK, Aidonis DA, Iakovou ET (2014) Agrifood supply chain management: A comprehensive hierarchical decision-making framework and a critical taxonomy. Biosyst Eng 120: 47-64.

14. Paydar MM, Cheraghalipour A, Keshteli MH (2018) A Bi-Objective stochastic mathematical model for agricultural supply chain network. In: Int Conf Supply Chain Logist Manag, World Academy of Science, Engineering and Technology, International Science Index, Industrial and Manufacturing Engineering, Dubai, p. 1545.

15. Roghanian E, Cheraghalipour A (2019) Addressing a set of metaheuristics to solve a multi-objective model for closed-loop citrus supply chain considering $\mathrm{CO}_{2}$ emissions. J Clean Prod 239: 118081.

16. Cheraghalipour A, keshteli MH (2017) Tree Growth Algorithm (TGA ): An effective metaheuristic algorithm inspired by trees behavior. In: $13^{\text {th }}$ Int Conf Ind Eng, Scientific Information Databases, Babolsar, Iran, 13: 1-8.

17. Cheraghalipour A, Keshteli MH, Paydar MM (2018) Tree Growth Algorithm (TGA): A novel approach for solving optimization problems. Eng Appl Artif Intell 72: 393-414.

18. Willis C, Hanlon W (1976) Temporal model for long-run orchard decisions. Can J Agric Econ 24(3): 17-28.

19. Starbird SA (1988) Optimal loading sequences for fresh-apple storage facilities. J Oper Res Soc 39(10): 911-917.

20. Maia LOA, Lago RA, Qassim RY (1997) Selection of postharvest technology routes by mixed-integer linear programming. Int J Prod Econ 49(2): 85-90.

21. Broekmeulen R (1998) Operations management of distribution centers for vegetables and fruits. Int Trans Oper Res 5(6): 501-508. 
22. Gigler JK, Hendrix EMT, Heesen RA, van den Hazelkamp VGW, Meerdink G (2002) On optimisation of agri chains by dynamic programming. Eur J Oper Res 139(3): 613-625.

23. Hester SM, Cacho O (2003) Modelling apple orchard systems. Agric Syst $77(2): 137-154$.

24. Vitoriano B, Ortuño M, Recio B, Rubio F, Ayuso AA (2003) Two alternative models for farm management: Discrete versus continuous time horizon. Eur J Oper Res 144(3): 613-628.

25. AM Blanco, G Masini, N Petracci, JA Bandoni (2005) Operations management of a packaging plant in the fruit industry. J Food Eng 70(3): 299-307.

26. Filho JVC (2006) Orange harvesting scheduling management: a case study. J Oper Res Soc 57(6): 637-642.

27. Ortmann F, Vuuren J, Van Dyk F (2006) Modelling the South African fruit export infrastructure: A case study. Orion 22(1): 35-57.

28. Masini GL, Blanco AM, Petracci N, Bandoni JA (2011) Supply chain tactical optimization in the fruit industry. Process Syst Eng, Wiley-VCH Verlag GmbH \& Co. KGaA, Weinheim, Germany, pp. 121-172.

29. Ferrer JC, Mac Cawley A, Maturana S, Toloza S, Vera J (2008) An optimization approach for scheduling wine grape harvest operations. Int J Prod Econ 112(2): 985-999.

30. Cittadini ED, Lubbers MTMH, de Ridder N, van Keulen H, Claassen GDH (2008) Exploring options for farm-level strategic and tactical decisionmaking in fruit production systems of South Patagonia, Argentina. Agric Syst 98(3): 189-198.

31. Bai R, Burke EK, Kendall G (2008) Heuristic, meta-heuristic and hyperheuristic approaches for fresh produce inventory control and shelf space allocation. J Oper Res Soc 59(10): 1387-1397.

32. van der Vorst J, Tromp SO, van der Zee DJ (2009) Simulation modelling for food supply chain redesign; integrated decision making on product quality, sustainability and logistics. Int J Prod Res 47(23): 6611-6631.

33. Blackburn J, Scudder G (2009) Supply chain strategies for perishable products: The case of fresh produce. Prod Oper Manag 18(2): 129-137.

34. Arnaout JPM, Maatouk M (2010) Optimization of quality and operational costs through improved scheduling of harvest operations. Int Trans Oper Res 17(5): 595-605.
35. Bohle C, Maturana S, Vera J (2010) A robust optimization approach to wine grape harvesting scheduling. Eur J Oper Res 200(1): 245-252.

36. Amorim P, Günther HO, Lobo BA (2012) Multi-objective integrated production and distribution planning of perishable products. Int J Prod Econ 138(1): 89-101.

37. Yu Y, Wang Z, Liang L (2012) A vendor managed inventory supply chain with deteriorating raw materials and products. Int J Prod Econ 136(2): 266-274.

38. Banaeian N, Omid M, Ahmadi H (2012) Greenhouse strawberry production in Iran, efficient or inefficient in energy. Energy Effic 5: 201209.

39. Ampatzidis YG, Vougioukas SG, Whiting MD, Zhang Q (2013) Applying the machine repair model to improve efficiency of harvesting fruit. Biosyst Eng 120: 25-33.

40. Catalá LP, Durand GA, Blanco AM, Alberto BJ (2013) Mathematical model for strategic planning optimization in the pome fruit industry. Agric Syst 115: 63-71

41. Velychko $O$ (2014) Integrated modeling of solutions in the system of distributing logistics of a fruit and vegetable cooperative. Bus Theory Pract 15: 362-370.

42. Lambert GF, Lasserre AAA, Ackerman MM, Moras Sánchez CG, Rivera BOI, et al. (2014) An expert system for predicting orchard yield and fruit quality and is impact on the Persian lime supply chain. Eng Appl Artif Intell 33: 21-30.

43. Araya MCG, Silva WES, Espejo LGA (2015) Harvest planning in apple orchards using an optimization model. Int Ser Oper Res Manag Sci pp. 79-105.

44. Roig EN, Aragonés LM (2015) Optimal transport planning for the supply to a fruit logistic center. Int Ser Oper Res Manag Sci, 224: 163-177.

45. Anderson E, Monjardino M (2019) Contract design in agriculture supply chains with random yield. Eur J Oper Res 277: 1072-1082.

46. Carvajal J, Sarache W, Costa Y (2019) Addressing a robust decision in the sugarcane supply chain: Introduction of a new agricultural investment project in Colombia. Comput Electron Agric 157: 77-89. 